\title{
MEDIA PANICS IBU RUMAH TANGGA SETELAH MENGAKSES BERITA COVID-19
}

\author{
Lian Agustina Setiyaningsih \\ Program Studi Ilmu Komunikasi Universitas Merdeka Malang \\ Jalan Terusan raya Dieng No 62-64 Malang \\ lian.agustina@unmer.ac.id
}

\begin{abstract}
Media panics is an expression of panic in using media, it is a study of media effects. In the era of the pandemic, news about developments in social conditions, especially related to the increasing number of people who have contracted Covid-19 in Indonesia, has triggered panic media use. This study used a descriptive quantitative method by analyzing one variable, namely media panics of housewives. Respondents involved a number of 244 housewives in Indonesia. The sampling technique used was purposive sampling with descriptive analysis method. The results of this study prove that many housewives consume Covid-19 news, especially topics related to the increasing number of sufferers and the easy spread. This is caused by saturation of information, feeling disturbed, unable to avoid news, exposure and use of the media, and joining groups. whereas the factors that influence the unequal way of accepting the concept of modernity in media, cultural shocks of utilizing high-tech media, common habits, discourse panic
\end{abstract}

Keywords: media panics, housewives, news, covid-19

\begin{abstract}
Abstrak
Media panics merupakan ekspresi kepanikan dalam menggunakan media, merupakan kajian efek media. Era pandemic covid-19, berita mengenai perkembangan kondisi sosial terutama terkait semakin tingginya yang terjangkit di Indonesia menjadi pemicu kepanikan pengunaan media. Penelitian ini menggunakan metode deskriptif kuantitatif dengan menganalisis satu variabel media panics ibu rumah tangga. Responden yang dilibatkan sejumlah 244 ibu rumah tangga di Indonesia. Teknik sampling yang digunakan purposive sampling dengan metode analisis deskriptif. Hasil dari penelitian ini terbukti ibu rumah tangga banyak mengkonsumsi berita covid-19 terutama topik semakin tingginya penderita dan penyebarannya. Dari aktivitas penggunaan media yang demikian, kepanikan media dialami ibu rumah tangga. Penyebabnya adalah kejenuhan informasi, perasaan terganggu, tidak dapat menghindari berita, terpaan dan penggunaan media, serta bergabungnya dalam kelompok. Sedangkan faktor yang mempengaruhi cara penerimaan konsep modernitas bermedia, gegar budaya pemanfaatan media, persamaan kebiasaan, wacana kepanikan.
\end{abstract}

Kata kunci : media panics, ibu rumah tangga, berita, covid-19 


\section{PENDAHULUAN}

Covid-19 membawa banyak perubahan sosial dan pola komunikasi dalam kehidupan. Penetapan kebiasaan berinteraksi dengan social distancing menjadi perubahan pola komunikasi yang sangat signifikan. Dari yang awalnya komunikasi langsung menjadi komunikasi utama dalam kehidupan sehari-hari sekarang bergeser dengan drastis menuju komunikasi dengan menggunakan media. Hal ini dikarenakan adanya aturan pemberlakuan social distancing guna meminimalisasi angka penularan di Indonesia.

Kebiasaan individu dalam berkomunikasi dan berinteraksi satu sama lain dengan bertemu fisik tidak lagi menjadi prioritas ketika terjadinya pandemi, mempengaruhi motivasi berkomunikasi dengan media (Muslih, 2020). Pola komunikasi langsung yang digantikan dengan komunikasi dengan menggunakan media juga berdampak signifikan terhadap tatanan kehidupan sosial masyarakat Indonesia. Terutama terjadinya gegar budaya dalam pemanfaat media yang berbasis teknologi (Adisel, Gawdy, 2020). Seluruh sektor kehidupan melibatkan media berbasis teknologi untuk mendukung terselengganya kegiatan. Seperti misalnya komunikasi pendidikan sangat bergantung pada media yang berbasis teknologi dan internet (Firman, 2020). Komunikasi bisnis dan perdagangan yang selama ini sangat konvensional sekarang lebih mengedepankan perdaganagn online (Khasanah et al., 2020). Dalam komunikasi pemerintahan juga demikian, semua proses komunikasi bergantung pada media yang berbasis internet dan teknologi untuk merealisasikan program kerja (Fakhruroji et al., 2019).

Intensitas tinggi dalam pemanfaatan media yang berbasis teknologi membuat masyarakat memiliki kebiasaan baru. Termasuk tindakan dalam menyikapi segala informasi mengenai perkembangan kasus covid-19. Data kasus yang terkonfirmasi di Indonesia pertengahan Agustus 2020 sejumlah 130.718 pasien. Peningkatan jumlah kasus sebanyak 1.942 yang tersebar di seluruh Indonesia (Peta sebaran kasus covid-19, 2020). Seluruh informasi mengenai pandemik dengan mudah diakses di media mainstream dan media baru. Tingginya intensitas dalam pemanfaatan media membentuk budaya bermedia. Termasuk membuat keterikatan yang tinggi antara audiens dengan media. Seluruh berita mengenai covid-19 dengan mudah diakses melalui media (Sampurno et al., 2020). Media mainstream dan media baru membawa warna sendiri dalam membentuk opini dan konsep bagi masyarakat.

Sebaran informasi mengenai covid19 sangat beragam dan dapat diakses bebas di media. Media juga dengan intens melakukan ekspos terhadap pemberitaan pandemi. Hal ini menurut Zhang et al., (2020) membawa dampak yang cukup signifikan di semua kalangan, terutama mengubah pola komunikasi dinamisasi kehidupan. Studinya di Cina menjelaskan masyarakat lebih proaktif dalam mencari berita pandemi dan memiliki tingkat keingintahuan yang tinggi terkait perkembangan berita. L. Wang, et al., (2014) keterbukaan informasi pada masyarakat Cina mengenai informasi covid19 dapat dilihat dari tingkat konsumsi berita di media massa.

Kondisi serupa juga terjadi di Indonesia, banyak penduduk yang memposisikan diri sebagai audiens dan mengkonsumsi berita terkait covid-19. Audiens memposisikan diri mereka sebagai penerima sekaligus pembuat berita. Peran ganda tersebut membuat sebuah distorsi komunikasi dalam menggunakan media. Terlebih jika diperhatikan, ibu rumah tangga di Indonesia yang tergolong dalam usia produktif merupakan pengguna media baru dalam mengakses berita covid-19. Dalam 
Djunu (2016), pemanfaatan media baru bagi ibu rumah tangga lebih dominan sebagai fungsi komunikasi untuk mencari informasi hiburan. Aktivitas yang dilakukan meliputi mendengarkan lagu dan menonton video di youtube. Intensitas penggunaan yang cukup tinggi juga untuk keperluan mengakses media sosial facebook, dan instagram. Begitu juga menurut Setiyaningsih \& Jatmikowati (2019), ibu rumah tangga sering kali memanfaatkan media sosial untuk mengakses hiburan dan informasi. Praktik komudifikasi waktu luang oleh media terjadi dikarenakan mereka menggunakan whats app grup sebagai media utama dalam mencari dan menyebarluaskan informasi. Sehingga dalam Junaidi (2017), menyebutkan hal tersebut menjadikan legitimasi atas stereotype yang melekat dalam ibu rumah tangga, bahwa ibu rumah tangga merupakan penangguran. Dan merupakan kelompok yang sangat memiliki tingkat literasi yang rendah atas penggunaan media baru terutama yang berkaitan dengan media sosial.

Media panics tergolong dalam neuroticism, kepribadian memiliki tingkat kecenderungan terisolasi dan mengubah karakter melalui penggunaan kata dan teks di internet (Ando \& Sakamoto, 2008). Hal ini juga dibuktikan dalam beberapa penelitian menyatakan perubahan karakter mempengaruhi perilaku dan tindakan dalam komunikasi di internet (Lavoie \& Pychyl, 2001). Dalam Shahbudin (2020), deksripsi atas sikap diatas merupakan gejala atas sikap media panics. Dimana audiens mengalami perubahan sikap negatif menjadi sangat panik setelah mengkonsumsi konten dalam media baru. Perubahan sikap yang demikian membuat memunculkan efek negatif penggunaan media dengan kadar terpaan media yang cukup tinggi.

Penelitian ini merupakan penelitian pengembangan dari kajian ibu rumah tangga dan peneggunaan media baru. Dimana, ibu rumah tangga mendapatkan stereotype memiliki literasi rendah sehingga berpengaruh pada penggunaan dan fungsi media. Di sisi lain media juga memiliki kekuatan untk membentuk sikap audines, dimana desain konten mempengaruhi kognisi audiens (Triono \& Setiyaningsih, 2017). Dalam era pandemi, ibu rumah tangga banyak mengakses informasinya melalui media dan penelitian ini menguji efek penggunaan media baru terhadap sikap panik setelah penggunaan media tersebut. Bahkan mereka tidak melakukan kegiatan konfirmasi atas berita yang telah didapatkannya. Media panics terbentuk akibat dari penggunaan media dengan terpaan yang intensif tanpa dibarengi dengan literasi bermedia.

\section{METODE PENELITIAN}

Penelitian deskriptif kuantitatif ini menggambarkan dan menjelaskan tentang adanya fenomena media panics ibu rumah tangga setelah mengkonsumsi berita covid19. Metode deskriptif kuantitatif mengurai asumsi yang bersumber dari suatu objek penelitian (Wijaya, 2019). Objek penelitian berupa media panics yang dialami oleh ibu rumah tangga di Indonesia. Penelitian ini melibatkan 244 ibu rumah tangga yang tersebar dari seluruh pulau yang ada di Indonesia. Pengambilan sampling menggunakan purposive sampling, dengan tujuan mengatur prosentase atau kuota responden untuk merepresentasikan keterwakilan reponden dari setiap pulau yang ada di Indonesia. Langkah awal analisis data dilakukan dengan mendeskripsikan jumlah rata-rata pada masing-masing indikator. Kemudian melakukan analisis lanjutan dengan mendeskripsikan keterkaitan dengan teori maupun konsep yang telah ada. Langkah terakhir adalah melakukan penyimpulan atas temuan. 
JURNAL NOMOSLECA

Volume 6 Nomor 2, Oktober 2020

\section{HASIL DAN PEMBAHASAN}

\section{Konsumsi informasi covid-19}

Pemberlakuan kebijakan menjaga jarak membuat tatanan baru dan berdampak pada pola komunikasi yang diberlakukan dalam keseharian. Perubahan kebiasaan dalam mengakses informasi yang awalnya lebih pada komunikasi langsung berubah menjadi komunikasi bermedia. Dari perubahan sikap komunikasi bermedia juga berdampak pada peningkatan angka konsumsi informasi melalui media mainstream maupun media baru.

Media mainstream yang sering digunakan untuk mengakses berita maupun informasi mengenai covid-19 adalah televisi. Alasan pemilihan televisi adalah dapat memberikan informasi secara audio dan visual. Kekauatan audio-visual pada televisi membuat ibu rumah tangga lebih mudah memahami informasi yang sedang diakses.

Sedangkan media baru merupakan media yang berbasis internet, ibu rumah tangga di Indonesia menggunakan media sosial untuk mengakses informasi covid-19. Jenis media sosial yang digunakan meliputi facebook, intagram, whats app serta berita online. Dari hasil kuisioner yang telah disebar ke seluruh Indonesia, sebanyak 244 ibu rumah tangga mengisi kuisoner tersebar di 7 pulau di Indoensia. Responden terbanyak berasal dari pulai Jawa sebesar 122 orang dan terendah 9 orang dari Lombok.

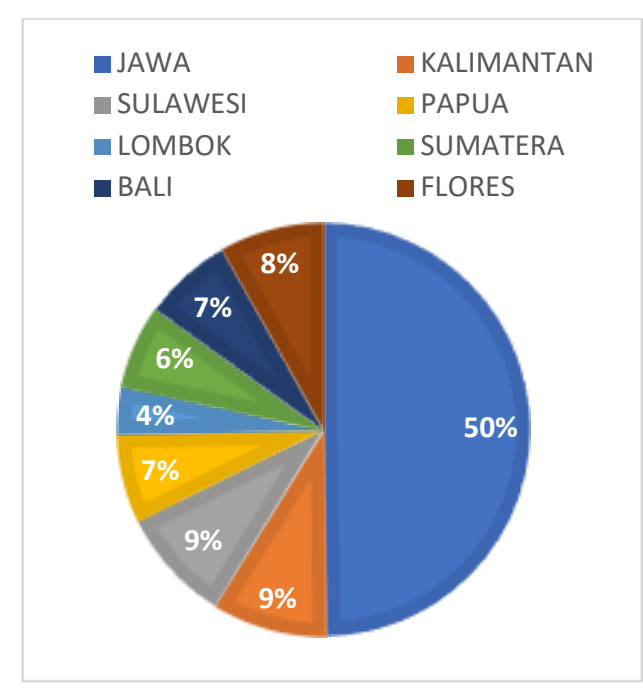

Gambar 1 Diagram Asal Pulau Responden

Sumber : data penelitian, 2020

Sebaran daerah dimaksudkan untuk menggali keragaman jawaban dan menggali banyak kemungkinan yang berkaitan dengan kepanikan setelah menggunakan media. Selain asal pulau, peneliti juga menggunakan indikator usia dengan membagi rentang usia mulai usia 20 hingga 60 tahun. Responden terbanyak merupakan ibu rumah tangga yang memiliki rentang usia antara 30-39 tahun dengan jumlah 128 responden.

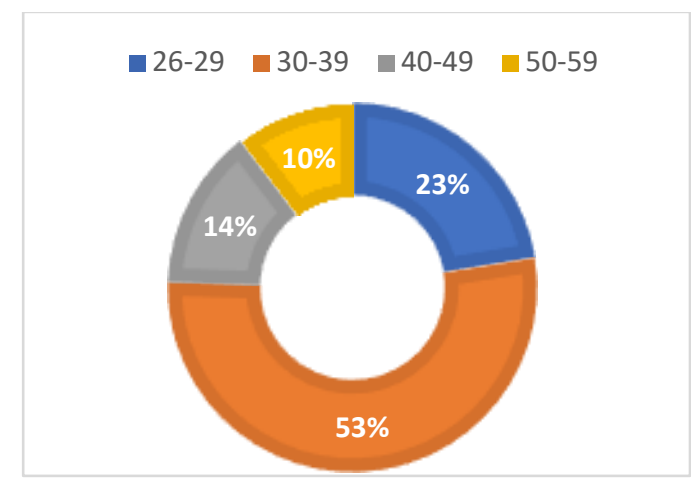

Gambar 2 Diagram Usia Responden

Sumber: data penelitian, 2020

Responden terbanyak dalam penelitian ini merupakan ibu rumah tangga yang berasal dari Pulau Jawa dengan 
rentang usia 30-39 tahun. Sejumlah 100\% ibu rumah tangga di Indonesia mengkonsumsi media tentang konten covid19. Ibu rumah tangga sangat tertarik dengan isu atau topik covid-19 terutama tentang semakin meningkatnya jumlah penderita yang terjangkit di Indonesia.

Konten atau isu mengenai covid-19 dianggap menarik sebesar 99,6\%. Dengan artian bahwa ibu rumah tangga menganggap berita ataupun informasi mengenai pandemi merupakan informasi atau berita yang sangat menarik saat ini jika dibandingkan dengan isu yang lainnya. Penyebab dari ketertarikan atas konten tersebut adalah faktor kedekatan (proximity). Ibu rumah tangga merasa penting mengakses tersebut karena kasus tersebut dekat dengan mereka terutama jika mereka mengakses jumlah penderita covid-19 berdasarkan daerah masing-masing.

Jika melihat sebaran usia terbanyak dalam penelitian ini yakni ibu rumah tangga antara 30-39 tahun, mereka memiliki karakteristik praktis dan dekat dengan media sosial. Hal sesuai dengan hasil penelitian dimana ibu rumah tangga banyak menggunakan media baru sebesar $69,3 \%$, sedangkan media mainstream $30,7 \%$. Alasan penggunaan media baru dikarenakan ibu rumah tangga sering kali menggunakan media sosial untuk mengakses informasi. Media yang digunakan meliputi youtube, facebook, instagram, whats app dan platform berita online.

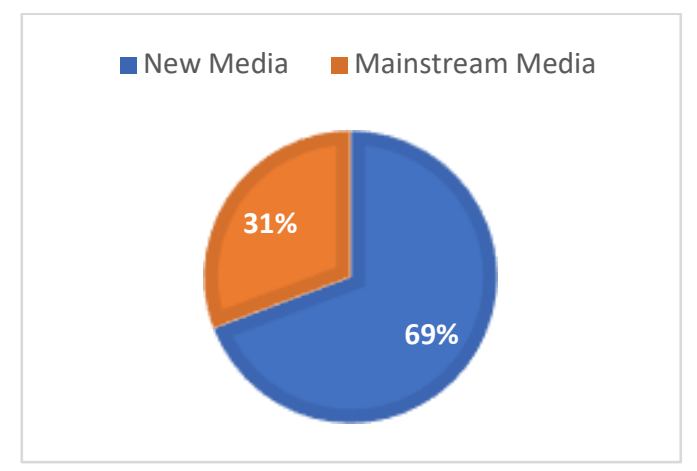

Gambar 3. Diagram Jenis Media Sumber: data penelitian, 2020
Ketertarikan yang tinggi responden pada media baru juga disebabkan mudah mengkases dan memiliki konten yang variatif serta selalu up to date (terkini). Afrilia (2017), alasan ibu rumah tangga dalam menggunakan media sosial adalah memberikan informasi terkini dan memotong pola komunikasi langsung dengan sesame ibu lainnya. Oleh karenanya, prosentase tertinggi ada pada penggunaan media baru.

Pemilihan media mainstream dikarenakan faktor usia diatas 40 tahun. Hal ini dikarenakan ibu rumah tangga belum terbiasa dengan penggunaan perangkat komunikasi berbasis teknologi tinggi. Mereka yang memiliki media mainstream sebagai sumber informasinya menjawab lebih praktis dan mudah dengan melihat televisi. Responden mengemukakan bahwa rata-rata lebih nyaman memilih televisi dikarenakan tidak bingung memilih sumber berita. Keterbatasan jumlah channel televisi menjadi pertimbangan utama dalam memudahkan ibu rumah tangga mengakses informasi covid-19.

Terpaan media pada kasus ini sangat tinggi. Artinya bahwa ibu rumah tangga memiliki intensitas yang tinggi dalam mengakses dan mengkonsumsi media massa. Responden menjawab serentak memiliki kebiasaan setiap hari mengakses informasi tersebut. Media massa juga memiliki intensitas yang tinggi dalam mengekspos pemberitaan pandemi. Terpaan media dapat dilihat dari frekuensi dan durasi responden dalam mengakses informasi di media massa baik media baru maupun media mainstream.

Frekuansi ibu rumah tangga dalam mengakses berita dan informasi mengenai covid-19 sebesar 99,2\%. Dengan kata lain ibu rumah tangga sangat sering mengakses informasi dan berita covid-19 di media massa. Sedangkan, durasi ibu rumah tangga dalam mengkonsumsi informasi dan berita covid-19 sangat lama sebesar 99,6\%. Rata- 
rata mereka mempunyai frekuensi 4-6 kali melihat berita maupun informasi pandemi dalam sehari, dengan durasi setiap melihatnya bekisar antara 30 menit hingga 1 jam.

Tingginya intensitas dan terpaan media tersebut dikarenakan ibu rumah tangga di seluruh Indonesia menganggap sumber berita dan informasi mereka memiliki kredibilitas yang tinggi. Hal ini ditunjukkan bahwa tingkat kepercayaan responden tentang kebenaran konten sebesar $99,8 \%$. Ibu rumah tangga sangat mempercayai berita dan informasi yang disampaikan baik di televisi maupun di media sosial.

Hal tersebut juga menceminkan tingginya tingat ketergantungan terhadap media massa dalam mengakses informasi dan berita mengenai covid-19. Sehingga konten berita yang diakses membuat ketakutan. Terlihat 99,2\% mengaku mengalami ketakukan setelah mengetahui perkembangan covid-19. Menurut ibu rumah tangga di Indonesia, mereka mengalami ketakutan hingga mengalami kekhawatiran sehingga membuat mereka untuk selalu mengakses informas guna menghapus ketidak pastian terkait penyebaran covid-19.

\section{Media Panics Ibu Rumah Tangga}

Dalam rangka menghapus ketidak pastian informasi dan mencari peneguhan agar merasa aman, ibu rumah tangga di Indonesia rela menghabiskan waktu mereka mencari informasi maupun berita covid-19 melalui media massa baik media sosial maupun televisi. Dari hasil penelitia, sebanyak $97,1 \%$ ibu rumah tangga merasakan keresahan setelah mengkonsumsi berita. Permasalahan ini menjadi seperti siklus tanpa akhir, yang awalnya ibu rumah tangga mencari informasi untuk peneguhan menjadi ancaman bagi mereka sendiri.
Mereka mengalami kepanikan setelah mengakses media massa yang disebabkan oleh tingginya terpaan. Kepanikan tersebut disebabkan oleh resah dalam menggunakan media sosial, takut tertukar covid-19, membeli bahan pokok berlebihan terkait kebijakan lockdown yang belum pasti, respon reaktif terhadap segala permasalahan. Hal tersebut rata-rata diakui sebagai penghambat saat membuat keputusan dalam kehidupan sehari-hari.

Kekuatan besar yang juga membentuk media panics adalah 96,3\% ibu rumah tangga rutin berbagi informasi dengan komunitas maupun kelompok. Hal inilah yang juga sangat mempengaruhi besarnya media panics di kalangan ibu rumah tangga. Kekuatan kelompok atau komunitas sangat mempengaruhi secara psikologis atas segala pembuatan keputusan dan perilaku anggotanya. Seperti misalnya di grup arisan, grup wali murid sekolah, grup dsa wisma dan grup lainnya ibu rumah tangga rutin membagikan informasi terkait dengan covid-19.

Responden mengaku 71,3 \% informasi yang mereka terima terserap semuanya dengan baik. Terutama jika informasi tersebut mereka dapatkan dari grup komunitas atau kelompok. 96,3\% ibu rumah tangga mengaku melibatkan komunitas atau keompok mereka dalam mengakses informasi dan berita covid-19. Dalam praktiknya, terbagi menjadi dua kelompok yakni ibu rumah tangga yang merasa ketakutan berbagi setelah mengakses infrormasi, dan yang kedua adalah ibu rumah tangga yang tidak takut berbagi informasi kembali di dalam kelompoknya. Fenomena tersebut dapat dilihat pada diagram di bawah ini. 


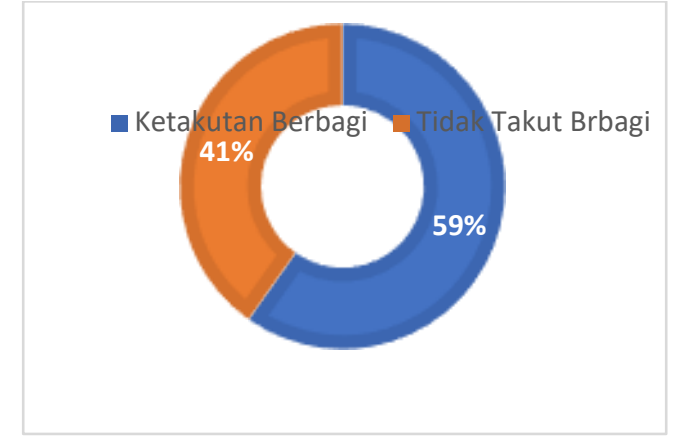

Gambar 4. Diagram Efek Penyebaran Informasi Dalam Kelompok

Sumber: data penelitian, 2020

Penyebab dari media panics adalah pertama, ibu rumah tangga mengalami kejenuhan atas konten yang sama. Ibu rumah tangga mengkonsumsi konten yang sama dalam durasi dan frekuensi yang cukup tinggi hal ini menciptakan media panics. Sebesar $98,4 \%$ responden mengaku jenuh dengan konten covid-19. Penyebab kedua,ibu rumah tangga tidak bisa menghindari konten berita dan informasi terkait topik tersebut. Sehingga mereka secara terpaksa mengkonsumsi atau mengkases berita tersbut. Sebesar $46 \%$ mengatakan bahwa menakses berita covid19 merupakan hiburan. Palmer (2006), kepanikan media muncul menggambarkan sebagai bagian dari tantangan atas penggunaan media. Tingkat tangung jawab soosial dalam pemanfaatan media mempengaruhi terbentuknya kepanikan media.

Penyebab ketiga adalah 97,1\% merasa tergangu dengan berita covid-19. Awalnya mengkonsumsi berita untuk mencari kenyamanan dan rasa aman, menjadikan ibu rumah tangga merasa tergannggu karena semakin banyaknya berita yang tidak bisa terelakkan. Penyebab keempat, terpaan media yang cukup tinggi sehingga secara frekuensi dan durasi ibu rumah tangga dianggap sebagai audiens memiliki ketergantungan dengan media massa.
Penyebab kelima, merupakan akumulasi dari semuanya yaitu ibu rumah tangga tergabung dalam satu kelompok atau komunitas. hal ini menyebabkan informasi berkumpul dan mengelilingi anggota kelompok sehingga tidak ada penyegaran informasi. Dan berakibat pada kejenuhan terhadap informasi dan berdampak pada perubahan perilaku menjadi panik setelah mengakses media massa. Kelompok atau komunitas bisa menjadi alasan media panics terjadi seperti dari hasil kajian literatur Buckingham \& Strandgaard (2012), kelompok merupakan sumber terbentuknya budaya kecil sehingga sangat memungkinkan media panics dipengaruhi oleh komunitas dan kelompok. Di sisi lain, gegar budaya juga merupakan bagian dari gejala media panics yang dialami oleh anggota sebuah komunitas atau kelompok.

Menurut Drotner (1999), faktor yang mempengaruhi terjadinya media panics adalah persamaan kebiasaan, persamaan terkait wacana panik, penerimaan moderinitas yang tidak total, gegar budaya. Dari paparan di atas, jika dipadukan dengan hasil penelitian, ada beberapa kesamaan faktor yang dapat mempengaruhi terbentuknya media panics sebagai sikap dan ekspresi pasca penggunaan media atas suatu konten.

Dari hasil survei, faktor yang pertama, adalah adanya cara penerimaan yang tidak sama atas konsep modernitas dalam bermedia. Ibu rumah tangga yang terletak di pulau jawa lebih mudah menerima perubahan dalam penggunaan media. Terlihat jika pilihan dari jenis media mereka mayoritas menggunakan media sosial dan tidak takut berbagi informasi kembali dengan yang lainnya. Kedua, gegar budaya dimana belum sepenuhnya ibu rumah tangga dapat menerima fungsi media sebagai perangkat teknologi yang dengan fungsi kompleks. Mereka masih memiliki kecenderungan hiburan dan informasi untuk pemanfaatan media. Sehingga masih terjadi 
kebingunngan terkait fungsi media yang sesungguhnya.

Faktor ketiga, persamaan kebiasaan sebagai ibu rumah tangga di Indonesia yang masih belum memiliki tingkat literasi yang tinggi berpengaruh terhadap pemaknaan isi media. Termasuk dalam menyikapi efek media pasca mengkonsumsi konten yang ada di dalamnya. Keempat, terbentuknya sikap panik yang dikarenakan sistem dan kondisi yang secara langsung disebabkan oleh penyebaran covid-19 yang tidak menentu. Kondisi in membentuk wacana kepanikan sehingga berimbas juga pada kebiasaan ibu rumah tangga intensitas tinggi dalam mengkonsumsi media massa.

\section{PENUTUP}

\section{Simpulan dan Saran}

Media panics merupakan ekspresi kepanikan dan juga dapat diangap sebagai sikap naik yang disebabkan karena penggunaan media. Semakin tingginya jumlah penduduk yang terjangkit covid-19 di Indonesia menjadi pemicu kepanikan pengunaan media. Ibu rumah tangga banyak yang mengkonsumsi berita covid-19 terutama topik terkait semakin tingginya angka penderita dan mudahnya penyebaran covid-19. Dari aktivitas penggunaan media yang demikian, kepanikan media dialami oleh ibu rumah tangga.

Faktor yang mempengaruhi terbentuknya media panics pada ibu rumah tangga adalah 1) cara penerimaan yang tidak sama atas konsep modernitas dalam bermedia, 2) gegar budaya terkait pemanfaatan media berteknologi tinggi, 3) persamaan kebiasaan akan kurangnya literasi bermedia terutama di media baru, 4) wacana kepanikan berdasarkan kasus covid19. Sedangkan penyebab terbentuknya media panics karena kejenuhan informasi dari ibu rumah tangga, merasa terganggu dengan konten yang ada, tidak dapat menghindari berita yang sedang beredar, terpaan dan penggunaan media yang terlalu tinggi dan bergabungnya ibu rumah tangga dengan kelompok atau komunitas.

\section{DAFTAR PUSTAKA}

Adisel, Gawdy, A. P. (2020). Penggunaan Teknologi Informasi dan Komunikasi dalam Sistem Manajemen Pembelajaran pada masa Pandemi Covid 19. ALIGNMENT: Journal of Administration and Educational Management, 3(1), 1-10. https://doi.org/10.1017/CBO97811074 15324.004

Afrilia, A. M. (2017). Penggunaan New Media Di Kalangan Ibu Muda Sebagai Media Parenting Masa Kini. Jurnal Komunikasi Dan Kajian Media, 1(1), 31-42.

https://doi.org/10.31002/JKKM.V1I1. 389

Ando, Reiko., Sakamoto, K. (2008). The effect of cyber-friends on loneliness and social anxiety: Differences between high and low self-evaluated physical attractiveness groups Author links open overlay panel. Computer In Human Behavior, 24(3), 993-1009. https://doi.org/10.1016/j.chb.2007.03. 003

Buckingham, D., \& Strandgaard Jensen, H. (2012). Beyond "Media Panics": Journal of Children and Media, 6(4), 413-429.

https://doi.org/10.1080/17482798.201 2.740415

Djunu, A. (2016). e- journal "Acta Diurna" Volume V. No. 5. Tahun 2016. Acta Djurna, $\quad V(5), \quad 1-15$. https://ejournal.unsrat.ac.id/index.php/ actadiurnakomunikasi/article/view/14 $276 / 13851$

Drotner, K. (1999). Dangerous Media? Panic Discourses and Dilemmas of 
Modernity. International Journal of Phytoremediation, 21(1), 593-619. https://doi.org/10.1080/003092399035 0303

Fakhruroji, M., Tresnawaty, B., Sumadiria, A. S. H., Risdayah, E., \& Kunci, K. (2019). Strategi Komunikasi Publik Penanganan COVID-19 di Indonesia : Perspektif Sosiologi Komunikasi Massa dan Agama. Ilmu Komunikasi UIN Sunan Gunung Djati Bandung, 1(1), 1-11. http://digilib.uinsgd.ac.id/30753/1/Stra tegi Komunikasi Publik Penanganan Covid_KTI.pdf

Firman, F. (2020). Dampak Covid-19 terhadap Pembelajaran di Perguruan Tinggi. BIOMA: Jurnal Biologi Dan Pembelajarannya, 2(1), 14-20. https://ojs.unsulbar.ac.id/index.php/bi oma/article/view/743

Peta sebaran kasus covid-19, (2020). https://covid19.go.id/peta-sebaran

Junaidi, H. (2017). Ibu Rumah Tangga: Streotype Perempuan Pengangguran. An Nisa'a, 12(1), 77-88. http://jurnal.radenfatah.ac.id/index.ph p/annisa/article/view/1475/1170

Khasanah, F. N., Samsiana, S., \& Handayanto, R. T. (2020). Pemanfaatan Media Sosial dan Ecommerce Sebagai Media Pemasaran Dalam Mendukung Peluang Usaha Mandiri Pada Masa Pandemi Covid 19. Jurnal Sains Teknologi Dalam Pemberdayaan Masyarakat (JSTPM), 1(1), 51-62. http://ejurnal.ubharajaya.ac.id/index.p hp/JSTPM/article/view/255/206

L. Wang, B. J. Cowling, P. Wu, J. Yu, F. Li, L. Zeng, J. T. Wu, Z. Li, G. M. Leung, H. Y. (2014). Human Exposure to Live Poultry and Psychological and Behavioral Responses to. Emerging
Infectious Diseases, 20(8), 1296-1305. https://doi.org/10.3201/eid2008.13182 1 Medline

Lavoie, J. A. \& Pychyl, T. A. (2001). Cyberslacking and the procrastination superhighway: A web based survey of online procrastination, attitudes and emotion. Social Sciences Computer Review, 19(1), 431-444.

Muslih, B. (2020). Urgensi Komunikasi dalam Menumbuhkan Motivasi di Era. Jurnal Penelitian Manajemen Terapan (PENATARAN), 5(1), 57-65. http://journal.stieken.ac.id/index.php/p enataran/article/view/463/542

Palmer, S. (2006). Toxic childhood: How the modern world is damaging our children and what we can do about it. Orion.

Sampurno, M. B. T., Kusumandyoko, T. C., \& Islam, M. A. (2020). Budaya Media Sosial, Edukasi Masyarakat, dan Pandemi COVID-19. SALAM: Jurnal Sosial Dan Budaya Syar-I, 7(5). https://doi.org/10.15408/sjsbs.v7i5.15 210

Setiyaningsih, Lian Agustina; Jatmikowati, S. H. (2019). NEW MEDIA IN COMMODIFICATION. ETTISAL: Journal of COmmunication, 4(1), 2534.

https://doi.org/10.21111/ettisal.v4i1.3 069

Shahbudin, M. S. I. (2020). Kepanikan Pengguna Media Sosial Terhadap Virus Covid 19. PENDETA Journal of Malay Language, Education, and Literature, $\quad 11, \quad 1-10$. http://ojs.upsi.edu.my/index.php/PEN DETA/article/view/3579

Triono, M. A., \& Setiyaningsih, L. A. (2017). Desain Disonansi Kognitif Sebagai Faktor Anteseden Untuk 
Volume 6 Nomor 2, Oktober 2020

Penguatan Kualitas Informasi Pada Website. Seminar Nasional Sistem Informasi, 1(1), 71-79. http://eprints.unmer.ac.id

Wijaya, H. (2019). Metode-Metode Penelitian Dalam Penulisan Jurnal Ilmiah Elektronik. 21-40. https://doi.org/10.31219/osf.io/dw7fq

Zhang, J., Litvinova, M., Liang, Y., Wang, Y., Wang, W., Zhao, S., Wu, Q., Merler, S., Viboud, C., Vespignani, A., Ajelli, M., \& Yu, H. (2020). Changes in contact patterns shape the dynamics of the COVID-19 outbreak in China. Science (New York, N.Y.), 368(6498), 1481-1486.

https://doi.org/10.1126/science.abb800 1 